\title{
McCune-Albright syndrome and acromegaly: hormonal control with use of cabergoline and long-acting somatostatin - case report
}

\author{
Síndrome de McCune-Albright associada à acromegalia: controle hormonal \\ com cabergolina e somatostatina de longa duração - relato de caso
}

João Paulo C. Almeida'1,2, Lucas Alverne F. Albuquerque ${ }^{1,2}$,

Camila L. H. Ferraz' ${ }^{1}$, Ítalo Mota' ${ }^{1}$, Jackson Gondim', Tânia M. B. L. Ferraz

Department of

Neuroendocrinology

Hospital Geral de Fortaleza

2 Universidade Federal do

Ceará (UFCE), Medical

School; Fortaleza, CE, Brazil.

\begin{abstract}
Objectives: The use of drug therapy based on cabergoline, octreotide and long-acting release (LAR) octreotide has presented varying results in the treatment of GH excessive production in patients with McCune-Albright Syndrome. Methods: We report the case of a 29 year-old female patient presenting McCune-Albright Syndrome and complaint of excessive bone growth. Results: The patient presented a pituitary adenoma involving the right internal carotid artery and excessive secretion of growth hormone (no GH suppression was observed after the oral glucose tolerance test). Due to the presence of diffuse thickness in skull base bones, surgical approach was not considered effective and the patient was submitted to drug therapy with octreotide LAR and cabergoline. At the one year follow-up, GH and IGF-1 levels were normal and no adverse effects were present. Conclusion: The use of drug therapy based on the association of cabergoline and octreotide is safe and able to achieve complete hormonal control in the treatment of acromegaly for McCune-Albright patients. Arq Bras Endocrinol Metab. 2009;53(1):102-106.
\end{abstract}

Keywords

McCune-Albright syndrome; acromegaly; pituitary adenoma; cabergoline; somatostatin

\section{RESUMO}

Correspondence to: João Paulo C. de Almeida

Rua Paulo Morais, 130

60175-175 Fortaleza, CE jpaulocavalcante@yahoo.com.br

Received in Sep/9/2008 Accepted in Jan/12/2009

Objetivo: O uso de terapia medicamentosa, como cabergolina, octreotide e octreotide de longa duração, tem apresentado resultados variados no tratamento da produção excessiva de hormônio de crescimento $(\mathrm{GH})$ em pacientes com síndrome de McCune-Albright. Métodos: Foi relatado o caso de uma paciente de 29 anos apresentando síndrome de McCune-Albright com queixas de crescimento ósseo excessivo. Resultados: A paciente apresentava adenoma pituitário com envolvimento da artéria carótida interna direita e produção excessiva de GH (sem supressão de GH após o teste de supressão com glicose). Por causa do aumento importante da espessura dos ossos da base do crânio, a abordagem cirúrgica foi considerada pouco efetiva e a paciente foi submetida à terapia medicamentosa com octreotide de longa duração e cabergolina. No seguimento de um ano, os níveis de GH e IGF-1 estavam normais e os efeitos adversos não eram presentes. Conclusão: A terapia medicamentosa fundamentada na associação de cabergolina e octreotide é segura e capaz de alcançar controle hormonal completo no tratamento de acromegalia na síndrome de McCune-Albright. Arq Bras Endocrinol Metab. 2009;53(1):102-106.

Descritores

Síndrome de McCune-Albright; acromegalia; adenoma pituitário; cabergolina; somatostatina

\section{INTRODUCTION}

$\mathrm{T}$ the original description of McCune-Albright Syndrome (MAS) includes the triad of poly/monostotic fibrous dysplasia, café-au-lait spots, and precocious puberty $(1,2)$. The signaling pathway of $\mathrm{G}$ protein, cAMP and adenylate cyclase is described to be affected in MAS (3-6). This pa- 
thway is involved in the production of the hormones MSH (melanocyte stimulating hormone), LH (luteinizing hormone), TSH (thyroid stimulating hormone), GH (growth hormone), and ACTH (adrenocorticotropin hormone) (6). G protein is constituted of alpha, beta and gamma subunits, and in MAS, the alpha subunit, encoded by the GNAS gene at the R201 position, is mutated, resulting in the constitutive activation of adenylate cyclase and high levels of intracellular cAMP (3-5).

Secondary to the development of autonomous cellular function in response to genetic mutation, endocrinopathies may be observed, such as hyperthyroidism, growth hormone $(\mathrm{GH})$ excess, renal phosphate wasting and Cushing syndrome $(3,6,7)$. Although rare, other organ systems may be affected: liver, heart, parathyroid and pancreas (8).

Hypersecretion of GH associated with MAS is unusual, only 51 cases of MAS and acromegaly have been reported in English literature until 2002 (9). The association of MAS and hypersecretion of $\mathrm{GH}$ is estimated to happen in $21 \%$ of the cases (3). Treatment of such patients may be very difficult once surgical excision is frequently not possible because of anatomic bone alterations; radiotherapy may precipitate sarcomatous transformation (10-13), and pharmacological treatment with somatostatin analogues may only be partially effective $(3,14)$.

We present a case of MAS associated with acromegaly, treated effectively with long-acting octreotide and cabergoline. Informed consent was obtained for the production of this paper.

\section{CASE REPORT}

A 29 year-old female patient was admitted to our department with the chief complaint of bone growth and breast discharge. There was premature sexual development, with menarche at nine years old, followed by two years of irregular menstruation. At the age of ten she started to present abnormal progressive growth of cranial bones, mainly in the left hemiface. She also reported a three-year history of fibrous dysplasia, diagnosed by biopsy of bone growth mass, and a two-year history of diabetes mellitus. At the age of 28 she developed amenorrhea and galactorrhea.

On physical examination, her height was $171 \mathrm{~cm}$ (target height: $148 \mathrm{~cm}$ ); she presented facial asymmetry with coarse features and acral enlargement with caféau-lait macules in the left hemithorax and in the dorsal region (Figure 1). No other alteration was detected on physical examination.

Laboratorial investigation demonstrated: basal GH (growth hormone) was $2.8 \mu \mathrm{g} / \mathrm{L}$ (normal range $<0.4$ $\mu \mathrm{g} / \mathrm{L}$, chemiluminescence assay) and there was no suppression of $\mathrm{GH}$ after the oral glucose tolerance test (OGTT) - nadir of $3.4 \mu \mathrm{g} / \mathrm{L}$ at 120 minutes (normal range $<1 \mu \mathrm{g} / \mathrm{L}$, chemiluminescence assay); IGF-1 was $352 \mathrm{ng} / \mathrm{mL}$ (normal range 117-329 ng/mL, chemiluminescence assay), serum prolactin $177.0 \mu \mathrm{g} / \mathrm{L}$ (normal range: $20 \mu \mathrm{g} / \mathrm{L}$, chemiluminescence enzyme immunoassay), PTH $81.8 \mathrm{pg} / \mathrm{mL}$ (normal range $<65$ $\mathrm{pg} / \mathrm{ml}$, chemiluminescence immunoassay), free T4 0.7 $\mathrm{ng} / \mathrm{dL}$ (normal range 0.7-1.48 ng/dL, quantitative chemiluminescence immunoassay), FSH: $1.2 \mathrm{mUI} /$ $\mathrm{mL}$ (normal range 3.5-12.5 mUI/ml, electrochemiluminescence assay), estradiol $20 \mathrm{pg} / \mathrm{mL}$ (normal range $12.5-166 \mathrm{pg} / \mathrm{ml}$, electrochemiluminescence assay), $\mathrm{LH}$ $0.5 \mathrm{mU} / \mathrm{mL}$ (normal range $2.4-12.6 \mathrm{mUI} / \mathrm{ml}$, electrochemiluminescence assay), alkaline phosphatase 537.9 IU/L (normal range 44 to 147 IU/L, conjugated antiantibody on Western blots), serum cortisol after $1 \mathrm{mg}$ dexamethasone suppression test $0.4 \mu \mathrm{g} / \mathrm{dL}$ (normal range $<1.8 \mu \mathrm{g} / \mathrm{dL}$, chemiluminescence assay).

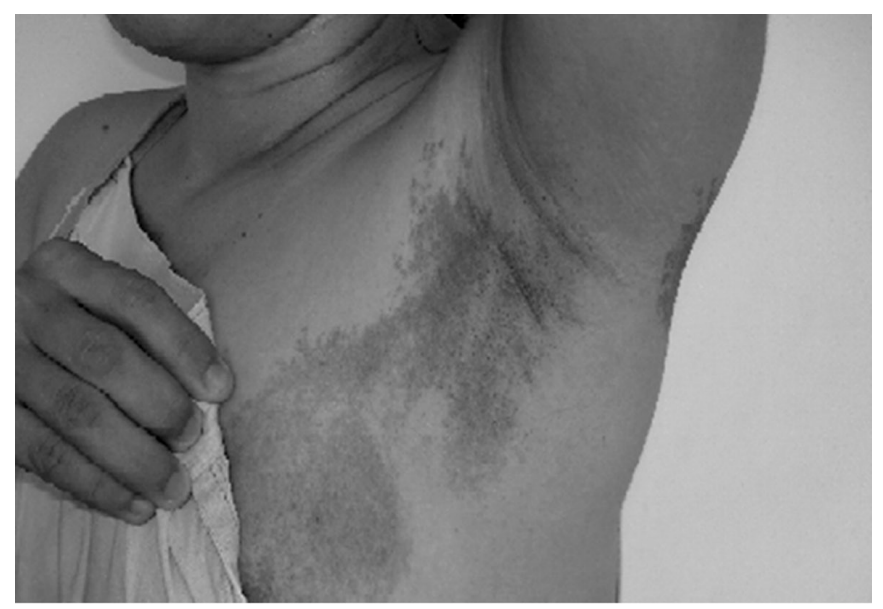

Figure 1. Café-au-lait spots in the left hemithorax.

Tibia X-ray demonstrated suggestive alteration of fibrous dysplasia (Figure 2); pelvic X-ray showed protrusion of the right acetabular articulation. Pituitary MRI (Figure 3) showed a $19 \times 12 \times 11 \mathrm{~mm}$ pituitary adenoma involving the right carotid artery, presenting minimal compression over the optic chiasm and important distortion and enlargement of the skull anatomy, mainly in the temporal, parietal, and sphenoidal bones of the right side (Figure 4). 


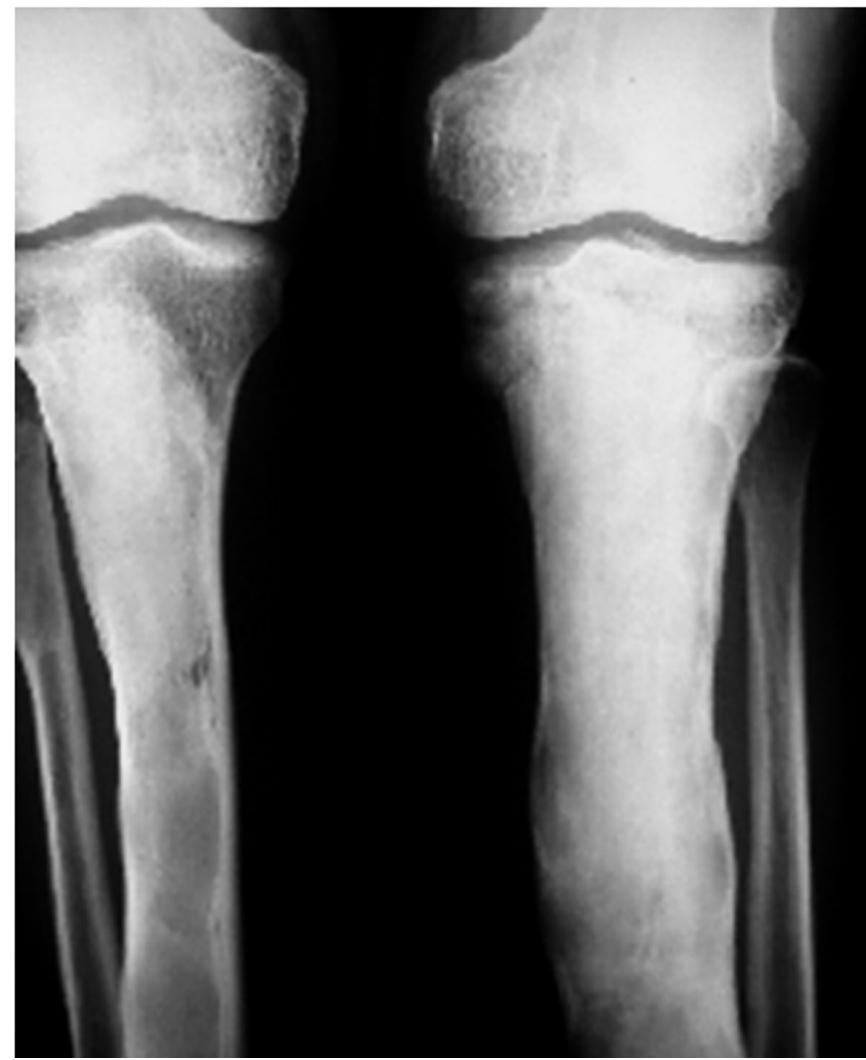

Figure 2. Anteroposterior X-ray of the proximal portion of the tibia, demonstrating important bone dysplasia.

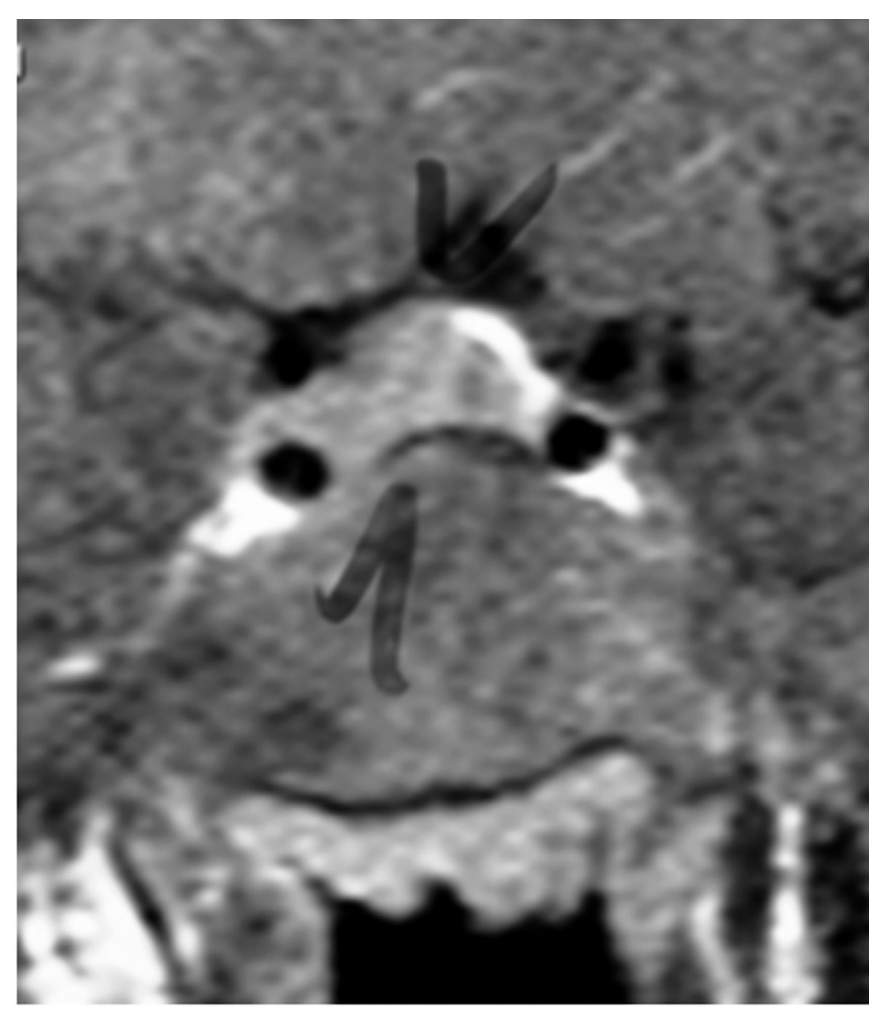

Figure 3. Coronal T1 Weighted MRI of the sella turcica, demonstrating pituitary macroadenoma with para-sellar invasion, involving the right internal carotid artery.

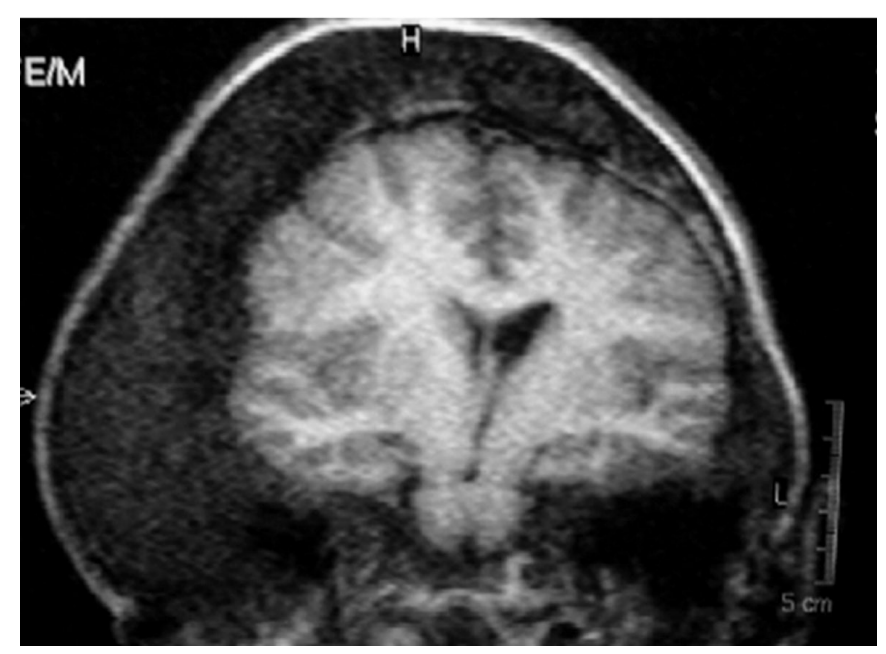

Figure 4. Coronal $\mathrm{T} 1$ Weighted $\mathrm{MRI}$ showing the cranial bone dysplasia.

A transsphenoidal approach to the pituitary region was not feasible because of anatomic bone distortions at the skull base. The patient was then submitted to pharmacological treatment with long-acting octreotide (10 mg intramuscular/month) and cabergoline (0.25 $\mathrm{mg}$ twice/month). At the one year follow-up there was hormonal control with the use of drug therapy: $\mathrm{GH}$ after OGTT was $<1 \mu \mathrm{g} / \mathrm{L}$ and IGF- 1 was $301 \mathrm{ng} / \mathrm{mL}$. No important side effects were observed. The craniofacial alterations presented are now under supervision of the plastic surgery team of our hospital for possible reconstructive treatment.

\section{DISCUSSION}

Presence of poly/monostotic fibrous dysplasia, cutaneous pigmented macules and hypersecretory endocrinopathies are the major characteristics of MAS. The occurrence of two of those lesions is sufficient for diagnosis of the Syndrome $(1,2)$.

Excess of growth hormone $(\mathrm{GH})$ and prolactin are the most frequent pituitary hormonal alterations in the Syndrome. Patients with MAS and GH hypersecretion are usually younger than 20 years old at onset and diagnosed on the basis of growth acceleration rather than facial dysmorphism, which is frequently difficult to assess due to fibrous dysplasia $(14,15)$. Only half of the patients with MAS and acromegaly present radiological evidence of a pituitary mass compared to $80 \%$ in classical cases of acromegaly $(6,15)$. $\mathrm{GH}$ excess has been shown to be associated with visual and auditory dysfunction, and macrocephaly in patients with MAS (9). There is prevalence of $85 \%$ of 
hyperprolactinemia in patients with MAS and acromegaly (6).

Effective treatment of patients with MAS and acromegaly may be difficult to achieve. Surgery, radiotherapy and medication are the options for such cases. Surgical approach may be extremely hard to be performed in patients once skull base bone alterations, usually present, do not allow adequate access to the sella region by the transsphenoidal approach (6). Radiotherapy has not been considered for the initial treatment of such cases because it might be associated with bone sarcomatous transformation $(12,13)$. Drug treatment with octreotide, long-acting release (LAR) octreotide or cabergoline have been used with varying results $(3,16-18)$.

The effects of somatostatin analogues on $\mathrm{GH} /$ IGF-1 hypersecretion as a first line therapy for acromegaly have been reported by Maiza and cols. (19). The group followed, for up to 18 years, 36 acromegalic patients in use of somatostatin analogues as the first line treatment. They found GH levels $<2 \mu \mathrm{g} / \mathrm{L}$, normal IGF- 1 levels or both in $25(70 \%), 24(67 \%)$ and 21 $(58 \%)$ patients. Also, reduction of the tumor size was reported (mean reduction: $43 \%$ ). In patients partially responsive to somatostatin analogues, Maiza and cols. (19), recommend some options to optimize hormonal control: the addition of a dopamine agonist in case of associated hyperprolactinaemia or, when GH/IGF-1 hypersecretion is moderate $(20)$, surgical debulking in the case of significant adenoma volume $(21,22)$, or the addition of pegvisomant on a weekly basis as was proposed recently $(23,24)$.

In MAS-associated acromegaly, drug treatment with cabergoline and octreotide has been studied by Akintoye and cols. (3). Six out of seven patients (86\%) treated with cabergoline presented partial response to the treatment. None of the patients obtained complete IGF-1 control with use of cabergoline alone. Octreotide LAR treatment was able to normalize IGF-1 levels in $50 \%$ of the non-responder patients to cabergoline. Those who failed treatment with octreotide LAR alone did not experience effective results with the use of the combination of octreotide LAR and cabergoline. Case reports have demonstrated different results from drug therapy, varying from partial to complete hormonal control with the use of long-acting somatostatin $(16,17)$. Pegvisomant, a GH receptor antagonist extremely effective in patients with acromegaly, has been successfully used in MAS patients with GH hypersecretion (25). Galland and cols. describe complete
IGF-1 control with the use of pegvisomant in three MAS patients, non-responders to octreotide treatment (25). No adverse effects were observed during the 1524 months of follow-up (25).

In our patient, drug therapy with cabergoline and octreotide LAR was initiated after the decision of not submitting her to surgery, because of the thickening of the skull base bones impairing the access to the pituitary adenoma. Radiotherapy was excluded as a first line therapy because of the risk of sarcomatous transformation. The decision to initiate treatment with the association of the drugs was made based on the reports that: first, to optimize hormonal control in a patient with acromegaly the addition of a dopamine agonist can be made in case of associated hyperprolactinaemia (19); second, cabergoline alone has not been able to promote complete hormonal control of GH/IGF-1 levels (3).

At the one year follow-up, IGF-1 and GH presented in normal levels and no adverse effects were observed. Although we are presenting just one case, analyzing our experience with the data in literature, we believe that in patients with MAS and acromegaly that cannot be surgically approached adequately and in those who do not present important optic nerve compression, drug therapy based on the association of cabergoline and octreotide might represent a safe and useful treatment option.

The use of drug treatment in order to achieve hormonal control in such patients, however, is not absent of side effects. The use of cabergoline in association with octreotide-LAR has been related to the development of impaired glucose tolerance and gallstones, probably due to the side effects of octreotide $\operatorname{LAR}(3,26)$. Recently, Tajima and cols. (18) published the occurrence of impaired glucose tolerance and development of gallstones at the three-year follow-up of a 15-year-old boy presenting MAS and acromegaly, in use of octreotide LAR and cabergoline. Although no side effects have been presented so far in our patient, rigorous follow-up is necessary in order to identify late adverse effects.

In summary, we report a case of a 29-year-old female who presented to our clinic with McCune-Albright Syndrome and acromegaly. The patient has been successfully treated with cabergoline and octreotide LAR. At the one year follow-up, IGF-1 and GH levels were adequately controlled and there was no report of adverse effects secondary to drug treatment.

Disclosure: The authors report no conflict of interest related to the production of this paper. This paper was produced with no financial support. 


\section{REFERENCES}

1. McCune DJ. Osteitis fibrosa cystica: the case of a nine-year-old girl who also exhibits precocious puberty, multiple pigmentation of the skin and hyperthyroidism. Am J Dis Child. 1936;52:743-4.

2. Albright F, Butler AM, Hampton AO, Smith P. Syndrome characterized by osteitis fibrosa disseminata, areas, of pigmentation, and endocrine dysfunction, with precocious puberty in females: report of 5 cases. $\mathrm{N}$ Engl J Med. 1937;216:727-46.

3. Akintoye SO, Chebli C, Booher S, Feuillan P, Kushner H, Leroith D, et al. Characterization of gsp-mediated growth hormone excess in the context of McCune-Albright syndrome. J Clin Endocrinol Metab. 2002;87:5104-12.

4. Weinstein LS, Shenker A, Gejman PV, Merino MJ, Friedman E, Spiegel AM. Activating mutations of the stimulatory $\mathrm{G}$ protein in the McCuneAlbright syndrome. N Engl J Med. 1991;325(24):1688-95.

5. Obuobie K, Mullik V, Jones C, John R, Rees AE, Davies JS, et al. McCune-Albright syndrome: growth hormone dynamics in pregnancy. J Clin Endocrinol Metab. 2001;86(6):2456-8.

6. Dumitrescu CE, Collins MT. McCune-Albright syndrome. Orphanet J Rare Dis. 2008;19:3-12.

7. Weinstein LS, Yu S, Warner DR, Liu J. Endocrine manifestations of stimulatory $\mathrm{G}$ protein-subunit mutations and the role of genomic imprinting. Endocr Rev. 2001;22:675-705.

8. Shenker A, Weinstein LS, Moran A, Pescovitz OH, Charest NJ, Boney $\mathrm{CM}$, et al. Severe endocrine and nonendocrine manifestations of the McCune-Albright syndrome associated with activating mutations of stimulatory G protein GS. J Pediatr. 1993;123:509-18.

9. Bhansali A, Sharma BS, Sreenivasulu P, Singh P, Vashisth RK, Dash RJ. Acromegaly with fibrous dysplasia: McCune-Albright Syndrome - clinical studies in 3 cases and brief review of literature. Endocr J. 2003;50(6):793-9.

10. Mock D, Rosen IB. Osteosarcoma in irradiated fibrous dysplasia. J Oral Pathol. 1986;15:1-4.

11. Mortensen A, Bojsen-Moller M, Rasmussen P. Fibrous dysplasia of the skull with acromegaly and sarcomatous transformation. Two cases with a review of the literature. J Neurooncol. 1989;7:25-9.

12. Ruggieri P, Sim FH, Bond JR, Unni KK. Malignancies in fibrous dysplasia. Cancer. 1994;73:1411-4.

13. Hansen MR, Moffat JC. Osteosarcoma of the skull base after radiation therapy in a patient with McCune-Albright syndrome: case report. Skull Base. 2003;13:79-83.

14. Chanson P, Dib A, Visot A, Derome PJ. McCune-Albright syndrome and acromegaly: clinical studies and responses to treatment in five cases. Eur J Endocrinol. 1994;131:229-34.
15. Premawardhana LD, Vora JP, Mills R, Scanlon MF. Acromegaly and its treatment in the McCune-Albright syndrome. Clin Endocrinol (Oxf). 1992;36(6):605-8.

16. Schoof E, Dörr HG, Kiess W, Lüdecke DK, Freitag E, Zindel V, et al. Fiveyear follow-up of a 13-year-old boy with a pituitary adenoma causing gigantism-effect of octreotide therapy. Horm Res. 2004;61(4):184-9.

17. Feuillan PP, Jones J, Ross JL. Growth hormone hypersecretion in a girl with McCune-Albright syndrome: comparison with controls and response to a dose of long-acting somatostatin analog. J Clin Endocrinol Metab. 1995;80(4):1357-60.

18. Tajima T, Tsubaki J, Ishizu K, Jo W, Ishi N, Fujieda K. Case study of a 15-year-old boy with McCune-Albright syndrome combined with pituitary gigantism: effect of octreotide-long acting release (LAR) and cabergoline therapy. Endocr J. 2008;55(3):595-9.

19. Maiza JC, Vezzosi D, Matta M, Donadille F, Loubes-Lacroix F, Cournot $M$, et al. Long-term (up to 18 years) effects on $\mathrm{GH} / \mathrm{IGF}-1$ hypersecretion and tumour size of primary somatostatin analogue (SSTa) therapy in patients with $\mathrm{GH}$-secreting pituitary adenoma responsive to SSTa. Clin Endocrinol (Oxf). 2007;67(2):282-9.

20. Selvarajah D, Webster J, Ross R, Newell-Price J, Effectiveness of adding dopamine agonist therapy to long-acting somatostatin analogues in the management of acromegaly. Eur J Endocrinol. 2005;152:569-74.

21. Colao A, Attanasio R, Pivonello R, Cappabianca P, Cavallo LM, Lasio G, et al. Partial surgical removal of growth hormone-secreting pituitary tumors enhances the response to somatostatin analogs in acromegaly. J Clin Endocrinol Metab. 2005;91:85-92.

22. Petrossians P, Borges-Martins L, Espinoza C, Daly A, Betea D, ValdesSocin $\mathrm{H}$, et al. Gross total resection or debulking of pituitary adenomas improves hormonal control of acromegaly by somatostatin analogs. Eur J Endocrinol. 2005;152:61-6.

23. Feenstra J, de Herder WW, ten Have SM, van den Beld AW, Feelders MD, Janssen JA, et al. Combined therapy with somatostatin analogues and weekly pegvisomant in active acromegaly. Lancet. 2005;365:1644-6.

24. Jorgensen J, Feldt-Rasmussen U, Frystyk J, Chen J, Kristensen L, Hagen $\mathrm{C}$, et al. Cotreatment of acromegaly with a somatostatin analog and a growth hormone receptor antagonist. J Clin Endocrinol Metab. 2005;90:5627-31.

25. Galland F, Kamenicky P, Affres H, Reznik Y, Pontvert D, Le Bouc Y, et al. McCune-Albright syndrome and acromegaly: effects of hypothalamopituitary radiotherapy and/or pegvisomant in somatostatin analogresistant patients. J Clin Endocrinol Metab. 2006;91(12):4957-61.

26. Oshino S, Saitoh Y, Kasayama S, Arita N, Ohnishi T, Kohara H, et al. Short-term preoperative octreotide treatment of $\mathrm{GH}$-secreting pituitary adenoma: predictors of tumor shrinkage. Endocr J. 2006;53(1):125-32. 